\title{
Research and Comparative Analysis of Build Technology Programming in Java
}

\author{
Aren K. Mayilyan and Levon M. Hovsepyan \\ National Polytechnic University of Armenia \\ e-mail: mayilyan96@mail.ru, lehovsepyan@gmail.com
}

\begin{abstract}
Build tools have been studied in Java environment, and a comparable analysis has been done according to the following parameters: initial learning curve, the speed of different builds, complexity, plugins, documentation and community, developer tools integrity.
\end{abstract}

Keywords: Compilation, Project, Tool, Template, Script, Configuration, Logic, Concept, Binary.

\section{Introduction}

Many programmers start a project with selecting the language and framework for programming, then the most important problem is to choose the build and deploy tool, for what you need to know which parameters to compare and determine which is the most appropriate for the project to be performed. Developers spend a substantial amount of time doing mundane tasks like build and deployment that include:

$>$ Compiling the code

$>$ Packaging the binaries

$>$ Deploying the binaries to the test server

$>$ Testing the changes

$>$ Copying the code from one location to another

Build tools are programs that automate the creation of executable applications from source code. Building incorporates compiling, linking and packaging the code into a usable or executable form. In small projects, developers will often manually invoke the build process. This 
is not practical for larger projects, where it is very hard to keep track of what needs to be built, in what sequence, and what dependencies exist in the building process. Using an automation tool allows the build process to be more consistent [1].

\section{Definition and Comparative Analysis of Build Tools}

Apache Ant (Another Neat Tool) is a Java-based build tool from Apache Software Foundation. Apache Ant's build files are written in XML, and they take advantage of being open standard, portable and easy to understand [2].

Apache Maven is a software project management and comprehension tool. Based on the concept of a project object model (POM), Maven can manage a project's build, reporting and documentation from a central piece of information. Using maven we can build and manage any Java-based project [3].

Gradle is an open source, advanced general purpose build management system. It is built on ANT, Maven, and lvy repositories. It supports Groovy-based Domain Specific Language (DSL) over XML. [4]:

So, let's make a comparative analysis of the build tools described above and summarize in Table 1.

Table 1: Comparative analysis of build tools.

\begin{tabular}{|l|l|l|l|}
\hline \multirow{2}{*}{$\begin{array}{l}\text { Comparison } \\
\text { parameters }\end{array}$} & \multicolumn{3}{|c|}{ Build tools } \\
\cline { 2 - 4 } $\begin{array}{l}\text { Initial learning } \\
\text { curve }\end{array}$ & $\begin{array}{l}\text { Apache Ant } \\
\text { takes a long time for } \\
\text { the practical works } \\
\text { done for build tools, } \\
\text { dependency and XML. } \\
\text { There are a lot of } \\
\text { templates in internet. }\end{array}$ & $\begin{array}{l}\text { Apache Maven } \\
\text { hard thing to do and you } \\
\text { do not need to be familiar } \\
\text { with Maven to be able to } \\
\text { build and package the } \\
\text { artifact or run unit tests on } \\
\text { some existing project [5]. }\end{array}$ & $\begin{array}{l}\text { The learning curve for } \\
\text { Gradle is partially } \\
\text { affected by another JVM } \\
\text { language-Groovy. With } \\
\text { just a little } \\
\text { understanding of } \\
\text { Groovy, it is really easy } \\
\text { to get it working and } \\
\text { understand it } \\
\text { thoroughly. }\end{array}$ \\
\hline Different \\
builds speed & $\begin{array}{l}\text { Clean function without } \\
\text { tests lasts 7.378sec, } \\
\text { with tests - 13.496sec, } \\
\text { build function without } \\
\text { tests lasts 4.829sec, } \\
\text { with tests - 10.705sec. }\end{array}$ & $\begin{array}{l}\text { Clean function without } \\
\text { tests lasts 6.279sec, with } \\
\text { tests - 13.451sec, build } \\
\text { function without tests } \\
\text { lasts 5.552sec, with tests - } \\
\text { 13.357sec. }\end{array}$ & $\begin{array}{l}\text { Clean function without } \\
\text { tests lasts 3.342sec, with } \\
\text { tests - 13.081sec, build } \\
\text { function without tests } \\
\text { lasts 3.638sec, with tests } \\
-10.030 \text { sec. }\end{array}$ \\
& & & \\
& & & \\
& & & \\
\hline
\end{tabular}




\begin{tabular}{|c|c|c|c|}
\hline $\begin{array}{l}\text { Create and } \\
\text { maintain the } \\
\text { build script }\end{array}$ & $\begin{array}{l}\text { The complexity of Ant } \\
\text { build scripts varies a } \\
\text { lot, depending on what } \\
\text { you're trying to } \\
\text { accomplish. Especially } \\
\text { when dealing with } \\
\text { many targets, the } \\
\text { dependency graph } \\
\text { between them can } \\
\text { easily be unclear, but } \\
\text { still enjoy the benefit } \\
\text { of the dependencies } \\
\text { being explicitly stated } \\
\text { in the script! }\end{array}$ & $\begin{array}{l}\text { When reading Maven } \\
\text { build scripts, there are } \\
\text { some conventions that } \\
\text { you should be aware of } \\
\text { this is sometimes known } \\
\text { as "The Maven Way". } \\
\text { Mostly, this refers to } \\
\text { the super POM and } \\
\text { contains some relatively } \\
\text { non-obvious (i.e., } \\
\text { invisible) inheritance and } \\
\text { aggregation rules, giving } \\
\text { Maven an implicit order } \\
\text { of lifecycles. }\end{array}$ & $\begin{array}{l}\text { The readability of } \\
\text { Gradle build scripts is } \\
\text { quite simple. It depends } \\
\text { who wrote the script and } \\
\text { how, but in general, } \\
\text { while taking a look at } \\
\text { these scripts, it can } \\
\text { roughly see what is the } \\
\text { script doing, even } \\
\text { without much Groovy } \\
\text { experience. }\end{array}$ \\
\hline $\begin{array}{l}\text { Count } \\
\text { of plugins and } \\
\text { how simple it } \\
\text { is to customize } \\
\text { your own } \\
\text { plugins }\end{array}$ & $\begin{array}{l}\text { Ant has as many } \\
\text { plugins as Maven. } \\
\text { Creating your own } \\
\text { plugin is also as } \\
\text { simple as Maven, but } \\
\text { more specifications in } \\
\text { the script itself are } \\
\text { needed to make it } \\
\text { work. Can't write code } \\
\text { directly in the build } \\
\text { script. }\end{array}$ & $\begin{array}{l}\text { Sometimes Maven is } \\
\text { called “plugin execution } \\
\text { framework”, because if } \\
\text { you want to do something } \\
\text { that Maven currently } \\
\text { can't do, you'll need to } \\
\text { find a plugin or write one } \\
\text { yourself. There is simply } \\
\text { no other alternative. }\end{array}$ & $\begin{array}{l}\text { Excellent flexibility, but } \\
\text { the library of existing } \\
\text { plugins is meager- } \\
\text { perhaps since it's easy } \\
\text { to write your own } \\
\text { plugins, users might do } \\
\text { that rather than creating } \\
\text { and hosting plugins in } \\
\text { the community [6]. }\end{array}$ \\
\hline $\begin{array}{l}\text { Community and } \\
\text { documentation }\end{array}$ & $\begin{array}{l}\text { Many experts who } \\
\text { have used it for many } \\
\text { years, but the } \\
\text { community activity is } \\
\text { pretty much dead. } \\
\text { Documentation is } \\
\text { outdated looking but } \\
\text { sufficient [7]. }\end{array}$ & $\begin{array}{l}\text { Documentation is } \\
\text { relatively good, but the } \\
\text { community, forum and } \\
\text { activity is past its prime. }\end{array}$ & $\begin{array}{l}\text { A lot of active users, } \\
\text { wikis and excellent } \\
\text { documentation-all } \\
\text { backed up by } \\
\text { Gradleware, an actual } \\
\text { company that supports } \\
\text { the tool's ecosystem. } \\
\text { You can even email } \\
\text { someone who will } \\
\text { write back to you. It } \\
\text { has a free book. }\end{array}$ \\
\hline $\begin{array}{l}\text { Integration } \\
\text { with developer } \\
\text { tools }\end{array}$ & $\begin{array}{l}\text { It integrates in more } \\
\text { environment than the } \\
\text { gradle, but less than } \\
\text { maven. }\end{array}$ & $\begin{array}{l}\text { Full support for each tool } \\
\text { and every category. There } \\
\text { is a reason that the } \\
\text { majority of developers } \\
\text { use Maven, after all. }\end{array}$ & $\begin{array}{l}\text { Doesn't } \\
\text { integrate in very } \\
\text { old developer } \\
\text { tools, because is } \\
\text { a new build tool. }\end{array}$ \\
\hline
\end{tabular}

\section{Conclusion}

For initial training, maven and gradle build tools are preferred. If required to build simple and shorter scripts, then the gradle build tool is preferred. For the number of plugins, the preference is given to maven, but its own plugin is easier to write with gradle. All build tools can be selected from the viewpoint of study and acquaintance, however, gradle has more recent and plain documents, free book, and maven is also rich in documents, and most of them are outdated 
in the case of ANT. Maven integrates in all environments and is ideal for large projects. Gradle is more suitable for medium sized projects.

\title{
Referenses
}

[1] [Online]. Available: https://www.techopedia.com/definition/16359/build-tool

[2] [Online]. Available: https://www.tutorialspoint.com/ant/

[3] [Online]. Available: https://www.tutorialspoint.com/maven/

[4] [Online]. Available: https://www.tutorialspoint.com/gradle/

[5] [Online]. Available: https://www.baeldung.com/ant-maven-gradle

[6] [Online]. Available: https://technologyconversations.com/2014/06/18/build-tools/

[7] [Online]. Available: https://devopscube.com/list-of-popular-open-source-java-build-tools/

Submitted 08.06.2018, accepted 02.11.2018.

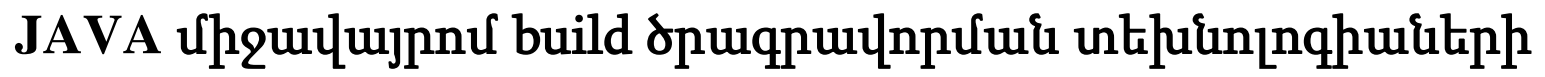

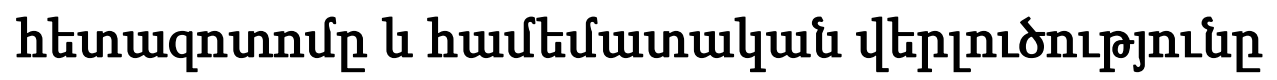

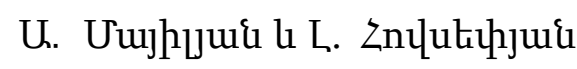

\section{Uựhnนhnıu}

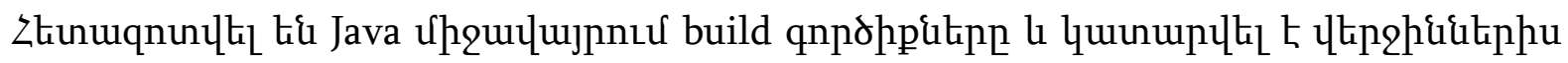

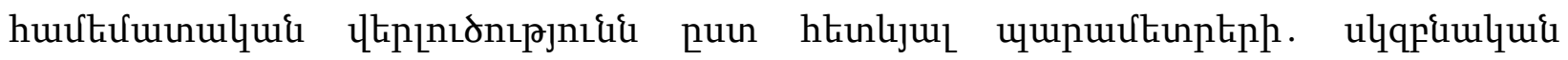

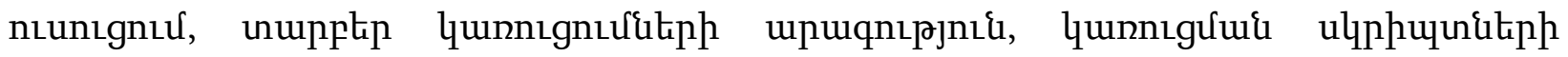

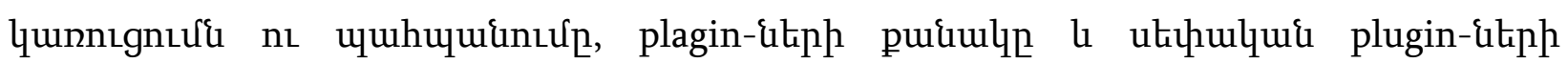

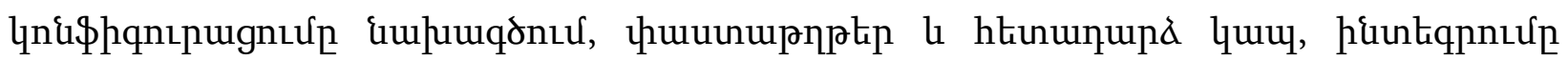

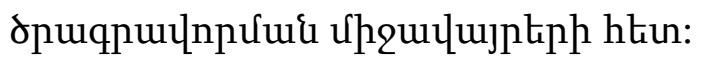

\section{Исследование и сравнительный анализ технологии build программирования в среде JAVA}

\author{
А. Маилян и Л. Овсепян
}

\begin{abstract}
Аннотация
Исследованы технологии build программирования в среде Java. Проведен сравнительный анализ по следуюшим параметрам: начальное знакомство, скорость построения, сложность, плагины, документация и обратная связь, интегрирование в программные среды.
\end{abstract}

